\title{
POST-NIGERIAN CIVIL WAR COMMUNITY RECONSTRUCTION STRATEGIES IN (ANIOMA) WESTERN IGBOLAND, 1970-1991
}

\author{
Daniel Olisa Iweze ${ }^{1}$ \\ Uchenna Anyanwu²
}

\section{Introduction}

The post-civil war reconstruction programme was promulgated by the Federal Military Government under General Yakubu Gowon at the end of the Nigerian Civil War for the reconstruction and rehabilitation of damaged infrastructure and reintegration of the Igbo into the matrix of the Nigerian state. The post-war policy of the Midwest State Government in its attempts at reconstructing Anioma (Western Igboland) at the end of the civil war was half-hearted and not genuine. The efforts pursued by both the Federal and Midwest State governments in assisting people to rehabilitate themselves and rebuild their social and economic infrastructure were marginal.

The post-civil war reconstruction programmes were laudable and noble, but their implementation was half-hearted, and subtly packaged to disempower and marginalize the lgbo. It fell short of people's expectations being reintegrated into the political and economic mainstream of the country. People adopted different communal self-help strategies to rehabilitate themselves after the Federal and State governments lost interest. After the war, the displaced Western Igbo people returned, rebuilt their residences, and when

\footnotetext{
I Department of History and International Studies, University of Benin. Benin City, Nigeria. E-mail: danielolisa2@gmail.com and daniel.Iweze@uniben.edu

2 Department of History and International Studies, University of Nigeria. Nsukka, Nigeria. E-mail: agucas200o@yahoo.com
} 
humanitarian aid stopped, they were left on their own. This propelled various communities in Western Igboland to rely on communal self-help efforts by mobilizing their socio-economic resources to rehabilitate their homelands.

At the end of the Nigerian Civil War in January I970, the pressing needs of the people were food, medication and shelter. Col. Ogbemudia, the Governor of the Midwest State, announced after the war that the Midwest State's needs for rehabilitation were more than its financial capacity and he urged people to initiate measures to rehabilitate themselves (Daily Times I970, 28). He further reiterated that the Midwest State Government could not provide all the social and economic services unless people were willing to perform their civic duties, and that rehabilitation work would be carried out by the government in collaboration with the people (Uchendu 2007, I73I74). The declaration of the Midwest State Military Governor, Ogbemudia, aptly typified the dire development needs of the people and the immense role the government expected from their self-help activities in complementing its efforts. During the reconstruction period, the dismal performances of both the Federal and Midwest State governments in restoring damaged infrastructure in Western Igboland created a lacuna which compelled people to embark on massive community and individual reconstruction work. This development aroused a revival of the spirit of self-help, which is deeply rooted in their tradition. This paper contends that the post-war reconstruction in Western Igboland was predominantly a communal and individual endeavour in which people's pragmatic efforts were only augmented by the assistance they received from the Midwest State and Federal governments as well as the humanitarian aid from local and international voluntary aid agencies and organizations.

Despite the historical relevance of the post-civil-war reconstruction programme in reintegrating the Igbo into Nigeria's fold after the war, there's a lack in literature exploring post-civil war reconstruction of Igboland. In Alex Harneit-Sievers, Jones Ahazuem and Sydney Emezue's work titled: A Social History of the Nigerian Civil War: Perspectives from Below (Harneit-Sievers, Ahazuem and Emezue I998), they focus on the impact of the Nigerian Civil War on the masses comprising the old, women and children. They maintain that these categories of people were the most vulnerable group who suffered greatly during the war. Edmund Egboh's work (I987) examines the contributions of town unions in the development of Igboland in the area of education, health care, electrification, water supply and other projects. It explores how town unions, social clubs, women associations and agegrades had served as agents of development in reconstructing their war-torn communities and social infrastructure damaged during the war. However, 
these works concentrated on the Igbo east of the Niger without making any reference to the Western Igbo people who suffered massive devastations and losses during the war.

The post-civil war reconstruction programme of Igboland cannot be studied without considering the prodigious works of Paul Obi-ani (2002) and Daniel Iweze (20I4). Obi-ani's work concentrates overly on the post-civil war reconstruction of social and economic infrastructure in Igboland east of the Niger while leaving the Western Igboland understudied. This tendency has made some scholars to believe, though erroneously, that Western Igboland is not part of Igboland. Iweze's work (20I4) focuses on the Midwest State Government under Col. Samuel Ogbemudia post-civil war reconstruction of Western Igboland. Apart from these works, until recently, there is no scholarly work that has been devoted exclusively to the study of the post-civil war community self-help strategies in Anioma (Western Igboland). It is given this historiographic gap that this paper explores the communal self-help strategies adopted by the people in reconstructing their homelands. It looks at the deplorable and unbearable conditions in Western Igboland during and after the war which made the population either stay at home or emigrate to other parts of the country and abroad. This paper assesses the successes and otherwise of the people's communal self-help efforts in rehabilitating themselves vis-a-vis the Federal and Midwest State government's reconstruction programmes.

\section{Geography and People of Western Igboland}

Geographically, Anioma comprised the then Asaba and Aboh Divisions of colonial Western Nigeria (Onyekpe 2002, 296). In the pre-colonial period, the people were variously called ndi Aniocha, ndi Ukwuani, ndi lka, ndi Odiani, ndi Oshimili, and Umu Ezechima, probably because they spoke lgbo language and occupied the western part of Igboland. Anioma people speak a distinct Igbo language with little dialectical and sub-cultural differences. The area was formerly administered as lka, Aniocha, Oshimili and Ndokwa local government areas (Ohadike I993). In the colonial period, it was called Western Igboland by the British ostensibly to differentiate them from the Igbo east of the River Niger and in the post-colonial period, it was called the lka Igbo in other parts of the Midwest region until the outbreak of the war. From the attainment of independence in I960 to I970s, the Western Igbo people, like other ethnic groups, in Nigeria developed a new form of consciousness aimed at seeking and redefining their identity. The name 
Anioma, literally means "people who live on the good and prosperous land" (Uchendu 2007, I6).

Anioma is an Igbo-speaking territory which belongs to the Kwa sub-group of the Niger-Congo language classification or family (Greenberg I99I, 304), who are ethnically homogenous. Anioma is made up of nine local government areas of Delta State, which occupy the northeast part of Delta State. It is bounded on the east by the river Niger; on the south by the Ijaw, on the west by the Urhobo, Isoko, and on the north by Benin and Ishan in Edo State. According to the I99I population census, Anioma had a population of 785,777 people (National Population Commission 2006 as cited in The Proposal for the Creation of Anioma State 2006, 4). With the creation of Delta State in I99I, the population has doubled due to the huge influx of people to Asaba, the capital, Agbor, Ogwuashi-Uku, Ibusa, Isselle-Uku and other cities.

\section{Map 1: Western Igboland}

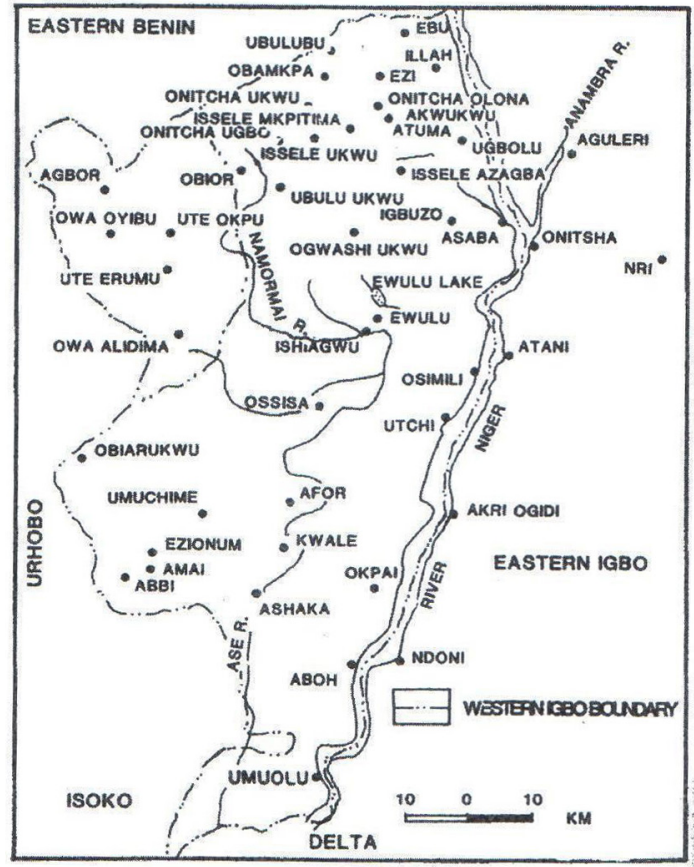

Source: Ohadike (1993, 76). 


\section{The Post-Civil War Reconstruction Programme by the Midwest State Government}

The post-civil war reconstruction programme of the Midwest State Government is examined under the social and economic rubrics. In the economic sphere, agricultural production was adversely affected by the war due to military movements. At the end of the civil war, the Midwest State Government urged the people to embark on agricultural production to ensure the success of the reconstruction programme. The Midwest State Government resuscitated the state-owned mechanized farms at Attache near Agbor and installed rubber processing equipment at Mbiri and Utagba-Uno farm settlements. The increase in agricultural yield helped in stabilizing the local economy. Asaba Textile Mill was reconstructed in I970 by the government in partnership with Messers Coutinho Caro of Hamburg (Okocha I994, I59).

The Federal and Midwest State governments prioritized the rehabilitation of transportation infrastructure by allocating funds to the sector. The Niger Bridge and Asaba-Benin-Lagos highway were reconstructed by the Federal Government based on the post-civil war National Development Plan of I970-I974 (National Development Plan of I973-I974, Programme of PostWar Reconstruction and Development.I973-I974,86). The state government reconstructed damaged roads and transport infrastructure, including the Oboshi Bridge linking Ibusa and Ogwuashi-Uku. However, many state and local roads and bridges were neglected and only rehabilitated by Col. George Ininh in 1974. From I976, Western Igboland began to have fairly good roads and transport businesses recovered from the devastations of the war. To mitigate the problem of road transportation, the Midwest State Government established the City Bus Service in Benin-City and later the Delta Bus Service in 1971. Township bus service was running in Agbor, Asaba, Sapele and other Divisional headquarters and Ogwuashi Uku, Warri and Auchi. The Midwest Line was later renamed Bendel Line (Ogbemudia I99I, 223-233). However, the setting up of the state-owned transport companies was inadequate to the transportation demands of the people.

Education received priority attention from the state government. The Midwest State Rehabilitation Committee in partnership with the international humanitarian aid agencies, such as the United States Agency for International Development (USAID), the American Friends Service Committee and the Quaker services rehabilitated many schools. In I97I, schools were reopened in Asaba, Ibusa, Okwe, Achalla-Ibusa and Ogwuashi-Uku. The Midwest State Scholarship Board endowed scholarships to indigent students and orphans 
up to secondary school level (Okocha I994, I63). The Midwest Institute of Technology was established in November I970 to solve the problem of displaced students and high demands for higher education in the state after the war (Ogbemudia I99I, 206-207). It was later upgraded and renamed the University of Benin in 1972.

To revamp the poor state of the health sector, the government built new hospitals in Akwukwu-Igbo, Ibusa and Olue-Olgbo in Isoko Division in I970. The Midwest State Health Management Board that was established in I97I built new hospitals and renovated existing ones (Ogbemudia I99I, 2I7-2I8). Several residential houses in Asaba, Ibusa, Ogwuashi-Uku, Oko, Ossisa and Isheagu were destroyed during the war. The government did not build new residential houses for the people, but only partnered with the United States Agency for International Development in the rehabilitation of houses in Asaba and Ibusa at the cost of $€_{315}, 000$. The government partnered with international aid agencies to distribute building materials to the people in Asaba, Ogwuashi-Uku, Ibusa, and Agbor (Uchendu 2007, I80-I8I). But these measures proved inadequate in meeting the housing needs of many communities.

The power supply that was disconnected by the Biafran forces in I967 in Asaba and neighbouring towns when they invaded the Midwest State was restored between I97I and 1972 (Ukpong I979, 83). Water supply equipment damaged during the war were restored in 1977 during Colonel Hussaini Abdullahi's regime (Asenime 2005, 322). The damaged post office and telecommunication facilities were not restored by the Midwest State and Federal governments. The Ibusa people's appeal to the Federal Government in August I970 for the rehabilitation of telecommunication and post office facilities was turned down. The Federal Government only released a paltry sum of $€ 5,000$ for the re-wiring of telephone lines in Agbor, Asaba, Ibusa and Ogwuashi-Uku (Daily Times I970, 6 as cited in Uchendu 2007, I79). The Western Igbo people, faced with grim despondency of the Midwest and Federal authorities, resorted to communal self-help in rebuilding their social and economic infrastructure.

\section{Western Igbo Post-Civil War Community Reconstruction Strategies}

The concept of community development encompasses strategies, interventions or coordinated activities at community level aimed at bringing 
about social and economic development (Idode I989). Before the advent of colonialism in Nigeria, many communities adopted communalism as a means for mobilizing community resources to provide functional facilities in aspects of their social, political and economic lives (Uchendu ig 65). They engaged in communal self-help in constructing their homes, clearing of farmlands, pathways, construction of bridges, the building of community halls and execution of other social infrastructural facilities.

Before the advent of Western-style development, Western Igbo communities like other Igbo societies lived by communal self-help and networking. Self-help, a relevant strategy for community development in Nigeria, is rooted in the rich tradition of the people. Most communities realized that the only way for immediate reconstruction of the war-ravaged homes and facilities was through self-help. The challenges of post-civil war situations were complex and multifaceted. The strategies used to address these challenges and effectively support the communities on a path of recovery and development were diverse. The period marked the revitalization and resuscitation of a multiplicity of town unions, associations and social clubs with aims and objectives that were consonant with the social insurance and self-help. Being the main strategy for community development in Nigeria, post-war community self-help concentrated on the provision of social amenities such as postal agencies, maternity centres, pipe-borne water, health and care. In effect, self-help succeeded where politics failed, due to the active participation, commitment and initiative of the people.

The most common institutional strategy was the town union, which combined social, economic, political and sometimes kinship ties. Each town union was based in a town or village in Igboland in which men and unmarried women joined with others from their home area, while married women affiliated with their husband's unions. Each union participated in two parallel networks, one that tied it to the hometown and another that tied it to migrant's place of residence. The hometown union was the headquarters which linked the branches across the migrant's place of residence and connected with branches in other migrant communities. As members of their hometown unions, migrant members could contribute to the development of their home communities. Town unions performed various functions by acting as resource and agency for social control for members and their families in times of need, emergencies and conflicts (For details see Isichei I976). The Midwest State Government's appeal for people to adopt self-help community development initiatives in reconstructing themselves helped them to revive various town unions, associations and social clubs. The aims and goals of these town unions and associations were to provide companionship, social 
security, preservation of the town's unity and culture and raise money to provide infrastructural facilities in the communities.

In Asaba, a town that was most ravaged by the civil war, the Asaba Urban District Council, (AUDC) and the Midwest State Government jointly reconstructed the Ogbe-Ogonogo and Ogbe-Olie markets in I970. Building materials were procured by the government, the A.U.D.C. paid for the labour (Okocha I994, I62). The Asaba Development Association, an offshoot of Asaba Urban District Council (AUDC) was established in I974 with Asagba of Asaba as its President. It set the pace for self-help community development initiatives with the following aims and objectives:

I. to promote and encourage the spirit of self-help in Asaba town;

II. to plan for the development of Asaba;

III. to raise and administer funds for the development and improvement of Asaba;

IV. to cooperate with organizations, unions or associations with identical aims and objectives to foster the welfare, development and progress of Asaba. (Asaba History and Development I978, 55)

One of the significant achievements of ADA was the building of Asaba Township Stadium, at the cost of N50,000, before it was taken over by the Bendel State Sports Council and later Delta State Sports Council. Another notable achievement was the reconstruction of Asagba`s Palace, damaged during the war, at the cost of $\mathrm{N}_{300,000}$ and NI,000 for the furnishing. ADA also built the Ogwa Uku Ahaba, its national secretariat at Ogbeilo quarters and reconstructed Ogbe-Eke Square, the venue where the Second Division of Nigerian army under the command of Col. Murtala Mohammed massacred Asaba people in October I967. To ease the transportation problem in Asaba, ADA ran municipal bus service to alleviate the local transportation problem of the people (Asaba History and Development i978, 48-54). It also founded the Niger Secondary School (Unoka 2008, Interview).

Social clubs were vital post-war community development centres with great social welfare potential. They evolved initially as a defensive mechanism for fostering the spirit of oneness and togetherness among the exclusive Igbo elites but later extended several welfare benefits to all categories of people. Like the town unions, social clubs performed social and utilitarian functions. Despite their marked elitist posture and negative class implications, they embraced a wider spectrum of Asaba population. These social clubs transcended merely guaranteeing organizational security, psychological support 
and financial relief to their respective members; they also made financial contributions to child care and war victims (Eteng 2002, 204).

Prominent among these social clubs was the Asaba Falcon Club whose membership comprised Asaba elites residing at home and abroad. It was founded in the mid-I97os to address development issues in Asaba. It executed many development projects and promoted sports and youth empowerment in Asaba. The feats of Asaba Development Association and Asaba Falcon Club encouraged Asaba womenfolk to form the Asaba Ladies League (ALL) in 1977 to provide development projects in Asaba and to mobilize funds for the welfare needs of its members. It was an inclusive association which embraced all categories of Asaba women. The Asaba Ladies League built a library in I977 and donated it to Oshimili Local Government Council. The library was later taken over by the Bendel State Government and renamed the Bendel State Library (Okolo 2020, Interview).

In the wake of the creation of Delta State in I99I, when there was a dire need for office spaces, Delta State Government used its secretariat at Nnebisi Road for some years until it completed its secretariat for civil servants. (Unoka 2008, Interview; Uchendu 2007, 205). The Asaba Elegant Ladies Club was founded in the mid-I970s and its membership was open only to elite women in Asaba. It contributed its quota in empowering the womenfolk through the disbursement of loans, credit facilities and other welfare packages to its members.

In Ibusa, a neighbouring town west of Asaba, the Ibusa Community Development Union was founded in 1942 with Obuzor of lbusa, Obi (Professor) Chiluno Nwaoboshi as chairman. It conducted people-oriented self-help projects in the town, among which was the building of Diokpa's Palace, the town's assembly hall where Obi Obuzor of lbusa and other traditional chiefs held meetings to deliberate issues affecting the town (Esedebe 20I0, Interview). The ICDU built the Ibusa town hall that served as an auxiliary clinic for the treatment of the sick and those that were wounded during the war (Nwaokocha 20I9, Interview). After the civil war; the town hall was converted to a secretariat for the Ibusa community vigilante group. The ICDU reconstructed the Ibusa post office which served towns and other communities in the defunct Asaba Division. It also renovated the Federal Government Girls' College Hall, at the cost of N2.5 million; constructed the Ogbe Atakpo Bridge, and built the St. Augustine's Grammar School, later renamed St. Augustine's College (Esogbue 2020, I37, I44 and 2I4).

The lbusa Premier Club and Ibusa People's Club branch were founded in the Ig 60 s to bring development projects to the town. In the post- 
war era, they focused on the reconstruction of schools, hospitals and other projects that were damaged during the war. The role of women organization was significant in the town. The Ibusa Women League, like its counterpart in Asaba, renovated some secondary schools and hospitals and carried out other community-based projects (Esedebe 20I0, Interview). These social clubs and organizations helped significantly to improve the living conditions of lbusa people, who struggled for survival after the civil war.

In Ogwuashi-Uku, the town's development association contributed immensely in lifting the town from the civil war devastations. The OgwuashiUku Beacon Club was the nucleus of the town's educated elite, comprised of Federal and State governments' civil servants, legal dignitaries, diplomats, and individuals in the academia, medical profession and private sector. Prominent members included Ambassador Ralph Uwaechue, Patrick Ozieh, Justice George Uwaechue (SAN), Prof. Emmanuel Osamor, the former Minister of Police Affairs, and (Obi) Professor Chukwuka Okonjo, the immediate past paramount traditional ruler of Ogwuashi-Uku kingdom (HRH Okonjo, 20IO). The communal self-help activities of the womenfolk were also considerable in Ogwushi-Uku. In I972, a female monarch, Omu was installed and she carried out many self-help projects which included the building of new stalls at Ogwuashi-Uku market. She and her cabinet members organized and supervised the activities of the town's market, set prices of foodstuffs and other items and enforced the rules and regulations in the market in the immediate post-war period. (Okonjo Mrs. 20I0, Interview).

In Oko, a neighbouring town south of Asaba, residential houses that were razed down during the civil war were reconstructed through community self-help efforts without any government intervention. Oko town, ten kilometres south of Asaba comprising the seven communities of Oko-Amakom, Oko-Anala, Oko-Ogbele, Oko-Umuoko, Aika-Ezeolu, Oko-Obiofu and Oko-Odifulu were devastated during the war. To attend to the educational demands of its people, the communities built two secondary schools in the I980s, named Oko Secondary School, located between Oko-Amakom and Oko-Anala, and Ekeanya Secondary School, built by Oko-Ogbele and UmuOko (Researcher`s observations). The two community secondary schools founded to meet people's demands for secondary education were later taken over by the Bendel Government and later Delta State Government. Due to age-long utter neglect of the community by successive governments in the provision of vital social infrastructures, Oko-Amakom and Oko-Anala villages executed electrification of their respective communities in the I980s. The two Oko communities raised funds to purchase big generators to provide electricity for them. Oko town was connected to the national grid through 
the efforts of the Oko Development Union with support from the Delta State Government. After the civil war, modern physical structures and infrastructural facilities at Oko town were built through communal and individual self-help efforts.

In Okpanam, north of Asaba, the town's community development interventions were immense. The people revived the Okpanam Community Development Union, which executed projects such as electricity, water supply and a post office. The London branch of OCGU donated books and other educational material to Okpalani Secondary School and erected the Major Chukwuma Kaduna Nzeogwu Statute at the centre of the town (Azubuogwu Augustine 20I0, Interview). The women's wing of OCDU reconstructed the Okpanam Health Centre and Emu-Ntoka road that links the town with the Asaba-Benin highway. The role of the female leader Omu of Okpanam, Her Royal Highness, Martha Dunkwu was considerable. She rebuilt the town market and constructed new stalls. The Okpanam community, in collaboration with Oshimili Local Government Council, built a new market at Okpanam at Asaba-Agbor-Benin-City highway (Ashibuogwu Elizabeth 2010, Interview). Iselle Mkpitime community built a maternity home and got an award of $£ 50$ aid from the Midwest State Government towards their self-help project. The Midwest State Government also disbursed a grant of $£ 50$ to Umu-Ekeke quarters in Akwukwu-lgbo for the completion of the building of fishing ponds (Uchendu 2007, 20I-203)

The Ubulu-Uku Development Union assisted immeasurably in the reconstruction of the damaged health centre, Ekumeku Grammar School and Iyi-Agor Grammar School and other projects in the town. The adoption of communal self-help efforts in Western Igboland during the reconstruction period was significant in other communities such as Iselle-Uku, Onicha-Olona, Isheagu, Ejeme-Aniogor, Agbor, Owa, lgbodo, Obior, Ubulu-Uku, Obiaruku amongst others. The palm oil industry was established at Akwukwu-Igbo, Ubulu-Uku and Nsukwa. Rubber Development Agency was established at Egbudu-Akah, Utagba-Uno and Kwale.

Western lgbo sons and daughters in diaspora, groups and organizations were the greatest offshore asset of their various communities because of their considerable human and financial capital potential, which they used for the benefit of their people. The diasporas comprised those that resided abroad before the war and those that migrated at the end of the war to escape the severe economic conditions that characterized the immediate post-civil war years, which offered them little or limited opportunities in terms of employment, social security and improvement in their general welfare. Examples 
are the Asaba Development Association, Ibusa Community Development Union, Okpanam Community Development Union, Ubulu-Uku Development Union and other community associations' branches in the United States of America, United Kingdom, Canada, Germany and others. They used their strategic positions in Europe, in the Americas and elsewhere to build up social and economic networks through which they channelled their wealth to their respective communities. Branches of town unions and clubs in Lagos, Ibadan, Abeokuta, Akure, Kano and others supported their towns through financial remittances after the war.

The diasporic town unions provided community-oriented projects, investment in the local enterprises, building and facilitating of transnational contact and networks with those at home and through the transfer of social capital badly needed in rebuilding the war-torn communities. Some of the diasporic associations endowed scholarships at home and contributed to the building and equipping local schools, hospitals and clinics, as well as in the construction of local roads in their respective communities. For example, Emma Okocha, one of the survivors of the killings in Asaba, was one of the beneficiaries of this scholarship and became trained as a journalist. The massive injection of financial capital by Western lgbo sons and daughters in the diaspora helped greatly in the reconstruction of both physical and social infrastructures. In this way, the diasporic communities acted as alternative agents for bolstering socio-economic development of their war-ravaged communities.

The establishment of the infrastructural projects served as veritable strategies used in addressing and/or overcoming the deficit in the restoration of infrastructure in Western Igboland by both the Federal and Midwest State governments. These infrastructural amenities effectively supported the communities and towns on the path of recovery and stimulated development in critical sectors of the economy. The success of the community self-help efforts was due to the active participation, commitment and initiative of the people who embarked on communal interventions in rebuilding key social infrastructure. The reliance of the people on community self-help efforts in improving their social and economic conditions with minimal interventions from the Federal and Midwest State governments shows that communal solidarity was encouraged when the state authorities abdicated their role in attending to the welfare needs of their citizens. The diminished government interventions had led to the rejuvenation of the spirit of self-help, as many communities tended to build on their local capabilities. This fostered a spirit of attachment, value and respect for projects, which constituted the need, yearning and aspiration of the people. 
Many communities in Western Igboland distinguished themselves in their enthusiasm for community development through self-help efforts. Alhaji Shehu Shagari, the post-war time Federal Commissioner for Economic Development, Rehabilitation and Reconstruction after an extensive tour of the war-affected areas commended the shared communal efforts of the people in self-help and posited that he was "impressed by the industry and the vigour of the people themselves, their towns and villages irrespective of the assistance from government and aid agencies. Public utilities were quickly reactivated as were other services and numerous forms of economic activities. Within a few years, what was once a desolate and seemingly hopeless case for development had witnessed an enormous transformation. The rapidity of the recovery would have been impossible without "the efforts of the community leaders in the war-affected areas" (Shagari 200I, I64). Reinforcing this view further, Chief Emmanuel Iwuanyawu posited that "the lgbo reconstructed their environment after the war when they could not get help from the appropriate quarters. They also rehabilitated themselves by turning to menial jobs and trade for survival after the war" (Okpaleke and Maduemesi 20II, 25). Community welfare service constituted one of the strategies adopted by the people through representative voluntary associations, unions, social clubs and individuals interested in community development projects (Anthony I996, I99-205 and 2002).

Although any state that emerges from armed conflict usually faces the difficult challenge of transitioning from war-weakened economies and highly polarized political and social relations to a revived economy capable of providing the basic needs of all citizens and political groups, the fact remains that without proper reconstruction of physical infrastructure and economic revitalization, the war-torn areas tend to remain handicapped. The government's failure in adequately addressing the needs of the people made them look inwards and search for solutions to their development problems through the mobilization of local resources. The Western Igbo people, like Igbo east of the River Niger, came out of the post-civil war programme of reconstruction rehabilitation and reintegration, otherwise tagged as the $3 \mathrm{Rs}$, impoverished, embittered and encumbered with debts.

The socio-economic conditions of various communities in the immediate post-war years were horrible, and therefore, a quick reminder of the plights of the Germans at the end of the Thirty Years War of i648. The Federal Government's claim of "no victor, no vanquished" was calculated to impress the people. Despite the adoption of various communal strategies by the population in improving their welfare and cushioning the effects of the Nigerian Civil War, the conditions at home were unbearable. Some, for 
various reasons such as the phobia of the I966 crisis in the north, and the subsequent horrible experiences during the civil war, decided to stay home and ventured into farming and other informal jobs to make a living. Others, who could not adapt to the post-war conditions at home, went back to their pre-war place of residence, while others went to Lagos, Ibadan, Kano, Jos, Kaduna and other cities.

\section{Conclusion}

This paper has explored the dynamics of community self-help reconstruction strategies adopted by the people in the post-civil war era. It has established that the survival instinct of the people motivated the adoption of communal self-help activities. These community development approaches in collaboration with governments and international agencies helped to improve their post-war conditions. Western lgbo people were disenchanted with the Midwest State and Federal governments' reconstruction programmes and decided to look inward, by adopting self-help strategies to rehabilitate themselves. To this end, the population's communal efforts were paramount for the restoration of physical infrastructure. Although both Federal and State governments reconstructed some damaged infrastructure, many communities were neglected. The post-civil war reconstruction programme in Nigeria under General Gowon has generated a lot of controversies and debates among scholars in academia and analysts outside the academic circles. Scholars who share the Federal Government's sentiments hastily point to a few reconstructed social amenities and argue that both the Federal and Midwest State governments did considerably well in reconstructing the war-torn areas after the hostilities. They commended the governments on the 'speed' with which the social and economic infrastructure was restored and reconciling the Igbo with other Nigerian groups. They believe that the Nigerian authorities were magnanimous in a victory which is unprecedented in global post-conflict reconstruction history. It would be misleading to weigh the paltry reconstruction of infrastructural facilities and limited rehabilitation of the people during the reconstruction era against the political and economic marginalization of the lgbo people and come to the conclusion that the Federal Government and the Midwest State's reconstruction programmes were faithfully implemented. The programme was implemented in a manner that reflected the pattern of marginalization and injustice to the people who were exposed to military operations and killings. In fairness, both Federal and Midwest governments did fairly well in the restoration of some basic infrastructure in Igboland, but 
the ulterior motive of marginalizing the lgbo was clear. Retributive measures inherent to the programme were at variance with the tenets of the post-civil reconstruction, rehabilitation and reintegration programme. The promulgators of the 3 Rs (Federal and Midwest State authorities), to some extent, lacked genuine commitment and political will in the implementation of the post-civil war reconstruction programme, as Igboland is still in the throes of being properly reconstructed. The post-civil reconstruction programme of the Midwest State government did not properly attend to the plight of the Western lgbo people. This is evidenced by the number of communal self-help efforts they initiated to address their pressing needs.

\section{References}

\section{Interviews}

Azubuogu, Augustine Cyril. (Aged 69), A former military officer in the Nigerian Army and Ex-Biafran soldier, Okpanam, December 30, 2010. He is the only surviving officer among the young revolutionary military officers that planned the January I966 coup that led to the death of the former Prime Minister, Alhaji Tafawa Belewa, Sarduana of Sokoto, Sir Ahmadu Bello, Chief Okotie-Eboh Finance Minister and other Northern military officers.

Azubuogu Elizabeth. (Aged 63), Retired School Teacher, Okpanam, December 30, 2010.

Esedebe, Fred. (Aged 77), Former Permanent Secretary in the defunct Midwest State Ministry of Information, Ibusa, June 28, 2010.

Nwaokocha, Augustine Odigwe, (Aged 56), Senior Academic, Ibusa, 3г December 20I9.

Okolo, Collins, (Aged 40), Doctoral candidate at the Institute of African Studies, University of Nigeria, Nsukka, Asaba, April ıo, 2020.

Okonjo, Chukwuka. (Aged 82), Retired Professor and Traditional Ruler of Ogwuashi-Uku Kingdom, Ogwuashi-Uku, July 22, 2010.

Okonjo, Kaneme. (Aged 76), Retired Professor, Ogwuashi-Uku, September 22, 2010.

Unoka, Ben. (Aged 73), Retired School Teacher, Asaba, December 28, 2008. 


\section{Books, Articles and Others}

Anthony, Douglas. I996. "I Need to Go to Kano": The Unmaking and Remaking of an Igbo Migrant Community in Northern Nigeria, I966I986, PhD Dissertation, Department of History, Northwest University, Evanston, Illinois. . 2002. Poison and Medicine, Ethnicity, Power, and Violence in a Nigerian City, 1966 to 1986. Portsmouth: Heinemann.

Asaba History and Development. I978. Benin-City: Manla Enterprises Nigeria Ltd.

Asenime, Jude. 2005. "The Foundation, Growth and Transformation of Asaba up to I99I", PhD Thesis, Bayero University, Kano.

Daily Times.I970, August 6. . I970. September 25.

Egboh, Edmund. I987. Community Development Efforts in Igboland. Onitsha: Etukokwu Press.

Esogbue, Emeka. 2020. A History of Ibusa: Origin, Settlement and Development of people Living Along the Road. Ibadan: Carophen Communication Limited

Eteng, I.A. 2002. "lgbo Community Development and Social Welfare". In Onitsha: Africana First Publisher A Survey of Igbo Nation, edited by G.E.F. Ofomata. Onitsha: Africana First Publishers Ltd.

Greenberg, Joseph. I98I. "African Linguistic Classification". In UNESCO General History of Africa: Methodology and African Pre-History, Vol.I, edited by Joseph Ki-Zerbo. California: Heinemann.

Harneit-Sievers, A., Ahazuem and J.O., Emezue, S. I998. A Social History of the Nigerian Civil War: Perspectives from Below. Enugu:

Idode, B. I989. Rural Development and Bureaucracy in Nigeria. Ibadan: Longman.

Isichei, E. 1976. A History of Igbo People. London: Longman.

Iweze, Daniel. 20I4, "Post Civil War Reconstruction of Western Igboland Nigeria, I970-I99I", Unpublished PhD Dissertation, Department of History and International Studies, University of Nigeria, Nsukka.

National Population Census, 2006. Federal Government of Nigeria, Abuja. Obi-ani, Paul. 2002. The Post-Civil War Social and Economic Reconstruction of Igboland, 1970-1983. Enugu: Markpress. 
Ogbemudia, S.O.I99ı. My Years of Challenge. Ibadan: Heinemann Educational Publishers.

Ohadike, Don. 1993, Anioma: A Social History of the Western Igbo People. Athens: Ohio University Press, xvi.

Okpaleke, D. and Maduemesi, Uche. 200I. "Echoes of Biafra". Tell Magazine 15 January, 25.

Okocha, Emma. I994, Blood on the Niger: The Untold Story of the Nigerian Civil War. Port-Harcourt: Sunray Publishers.

Okonjo, Kaneme. "The Dual Sex Political System in Operation: lgbo Women and Community Politics in Midwestern Nigeria". In Women in Africa, edited by Hafkin, N.J. and Bay, E. G. California: Stanford University Press.

Onyekpe, Nkem. 2002, "Conflict and Co-operation Among West Niger Igbo Communities Before 1900". In Readings in Nigerian History and Culture: Essays in Memory of Prof. J.A. Atanda, edited by G.O. Oguntomsin and Ademola Ajayi. Ibadan: Hope Publishers

Second National Development Plan 1970-74, Programme of Post-War Reconstruction and Development, Vol. ii, Lagos, Government Printer.

Shagari, Shehu. 2oor. Beckoned to Serve: An Autobiography. Ibadan: Heinemann Educational Books.

The Proposal for the Creation of Anioma State: Movement for the Creation of Anioma State Central Working Committee. 2010. June.

Uchendu, E. 2007. Women and Conflict in the Nigerian Civil War. Trenton: Africa World Press

Uchendu, V. C. I965, The lgbo of South-East Nigeria. Case Studies in Cultural Anthropology. New York: Holt Rhine Hart \& Winston.

Ukpong. I. I979, "Social and Economic Infrastructure". In Structure of the Nigerian Economy, edited by Olaleku, B., Fajana, Tomori and Ukpong. London: Macmillan Publishers and University of Lagos Press.

\section{ABSTRACT}

The Nigerian Civil War caused a lot of devastation in Igboland as a whole and the most pressing needs of the people were food, clothing and shelter. To tackle these challenges, the Nigerian Government under General Gowon introduced the postcivil war reconstruction programme to reconstruct Igboland. The reconstruction of western Igboland, (Anioma) in the Midwest State was undertaken by the Midwest State Government under Col. Ogbemudia. The Federal and Midwest State 
governments' efforts in the rehabilitation and reconstruction of damaged social and economic infrastructure in Anioma were inadequate and this compelled the people to embark on individual and communal self-help interventions. This paper explores the veritable self-help strategies the people adopted and contends that the reconstruction programmes were half-hearted, and subtly packaged to marginalize

and dominate the Western Igbo people in the economic and political affairs of the Midwest State and larger Nigeria. The overarching argument of the paper is that it was the valorised resilience of the people that was paramount in the reconstruction of their war-ravaged communities.

\section{KEYWORDS}

Western Igboland; Anioma; Community; Post-Civil War; Reconstruction Strategies.

Received on June 25, 2020

Accepted on October 1st, 2020 